Abstracta Iranica

Revue bibliographique pour le domaine irano-aryen

Volume 37-38-39 | 2018

Comptes rendus des publications de 2014-2016

\title{
Martin Heimgartner. Die Briefe 30-39 des Ostsyrischen Patriarchen Timotheos I
}

\section{Florence Jullien}

\section{(2) OpenEdition \\ 1 Journals}

\section{Édition électronique}

URL : http://journals.openedition.org/abstractairanica/45211

DOI : 10.4000/abstractairanica.45211

ISBN : 1961-960X

ISSN : 1961-960X

Éditeur :

CNRS (UMR 7528 Mondes iraniens et indiens), Éditions de l'IFRI

Référence électronique

Florence Jullien, « Martin Heimgartner. Die Briefe 30-39 des Ostsyrischen Patriarchen Timotheos I », Abstracta Iranica [En ligne], Volume 37-38-39 | 2018, document 37, mis en ligne le 30 décembre 2018, consulté le 02 octobre 2020. URL : http://journals.openedition.org/abstractairanica/45211 ; DOI : https://doi.org/10.4000/abstractairanica.45211

Ce document a été généré automatiquement le 2 octobre 2020.

Tous droits réservés 


\section{Martin Heimgartner. Die Briefe 30-39 des Ostsyrischen Patriarchen Timotheos I}

Florence Jullien

\section{RÉFÉRENCE}

Martin Heimgartner. Die Briefe 30-39 des Ostsyrischen Patriarchen Timotheos I. Louvain:

Peeters, 2016, V-XXXII-186 p. et V-XLII-162 p. ; ISBN 978-90-429-3298-2 et

978-90-429-3299-9, (CSCO 661-662, Script. Syr. 256-257)

1 L'A. poursuit ici son travail méticuleux d'édition de la correspondance du patriarche syro-oriental Timothée $\mathrm{I}^{\mathrm{er}}$ dans la collection du Corpus scriptorum christianorum orientalium chez Peeters, après avoir publié les Lettres 42 à 58 en 2012 (CSCO 644-645), ainsi que la disputatio du catholicos avec le calife al-Mahdī (CSCO 631-632) en 2011. Comme il le souligne dans les parties introductives, ces dix Lettres sont un précieux témoignage sur la situation de l'Église d'Orient en milieu islamique au VIII ${ }^{\mathrm{e}}-\mathrm{IX}^{\mathrm{e}}$ siècle. Les missives 34 à 36 reflètent ainsi une véritable réflexion biblique de controverse avec l'islam, notamment sur le thème du Christ serviteur dans le prisme du deutéro-Isaïe. Les Lettres 38 et 39 sont par ailleurs intéressantes sur les questions théologiques relatives au dyophysisme. Cette étude très solide se fonde sur un vaste ensemble de manuscrits, et constitue un travail de référence. 


\section{AUTEURS}

\section{FLORENCE JULLIEN}

CNRS, Mondes iranien et indien, Paris 